\title{
Fibrisoma limi gen. nov., sp. nov., a filamentous bacterium isolated from tidal flats
}

\author{
Manuela Filippini, ${ }^{1}$ Andres Kaech, ${ }^{2}$ Urs Ziegler $^{2}$ and Homayoun \\ C. Bagheri ${ }^{1}$ \\ ${ }^{1}$ Institute of Evolutionary Biology and Environmental Studies, University of Zurich, \\ Winterthurerstrasse 190, 8057 Zurich, Switzerland \\ ${ }^{2}$ Center for Microscopy and Image Analysis, University of Zurich, \\ Winterthurerstrasse 190, 8057 Zurich, Switzerland
}

Correspondence

Homayoun C. Bagheri

bagheri@ieu.uzh.ch

\begin{abstract}
An orange-pigmented, Gram-staining-negative, non-motile, filament-forming, rod-shaped bacterium (BUZ $3^{T}$ ) was isolated from a coastal mud sample from the North Sea

(Fedderwardersiel, Germany) and characterized taxonomically using a polyphasic approach.

According to $16 \mathrm{~S}$ rRNA gene sequence data, it belonged to the family Cytophagaceae, exhibiting Iow $16 \mathrm{~S}$ rRNA gene sequence similarity (<90\%) with members of the genera Spirosoma, Rudanella and Fibrella. The DNA G +C content was 52.0 mol\%. The major fatty acids were summed feature 3 (comprising $\mathrm{C}_{16: 1} \omega 7 \mathrm{c}$ and/or iso- $\mathrm{C}_{15: 0} 2-\mathrm{OH}$ ), $\mathrm{C}_{16: 1} \omega 5 \mathrm{c}$ and iso- $\mathrm{C}_{17: 0}$ $3-\mathrm{OH}$. The major polar lipids consisted of phosphatidylethanolamine and several aminolipids. On the basis of phenotypic, chemotaxonomic and phylogenetic data, it is proposed that strain BUZ $3^{\top}$ represents a novel genus and species, for which the name Fibrisoma limi gen. nov., sp. nov. is proposed. The type strain is BUZ $3^{\top}\left(=\mathrm{DSM} 22564^{\top}=\right.$ CCUG $\left.58137^{\top}\right)$.
\end{abstract}

The family Cytophagaceae constitutes a phylogenetically diverse group within the phylum Bacteroidetes (Ludwig et al., 2008) and contains 18 genera at the time of writing. Recently, two new genera were proposed: Rudanella, described by Weon et al. (2008), and Fibrella, described by Filippini et al. (2011). Novel species of the genus Spirosoma have also been characterized recently, namely Spirosoma rigui (Baik et al., 2007), Spirosoma panaciterrae (Ten et al., 2009), Spirosoma spitsbergense and Spirosoma luteum (Finster et al., 2009).

Strains BUZ $3^{\mathrm{T}}$ and BUZ 4 were isolated from a mud sample from tidal flats in Fedderwardersiel (53 $35^{\prime} 59^{\prime \prime} \mathrm{N}$, $8^{\circ} 21^{\prime} 23^{\prime \prime}$ E, elevation $0 \mathrm{~m}$ ), on the North Sea coast of Germany, while searching for agar-degrading bacteria. Colonies were isolated on a selective nutrient agar (Difco, Becton Dickinson) with $50 \mu \mathrm{g}$ kanamycin $\mathrm{ml}^{-1}$. The strains were cultured on R2A plates (Reasoner \& Geldreich, 1985) and maintained for long-term storage at $-80{ }^{\circ} \mathrm{C}$ in a glycerol suspension (1:1 mixture of glycerol and cell culture).

Bacterial genomic DNA was extracted using lysis buffer (KCl, Tris-base, Tween 20, pH 8) as described by Svercel et al. (2009). PCR was carried out with the universal

The GenBank/EMBL/DDBJ accession number for the 16S rRNA gene sequence of strain BUZ $3^{\top}$ is G0355622.

Two supplementary figures are available with the online version of this paper. bacterial primers $27 \mathrm{~F}$ and $1525 \mathrm{R}$ in a Techne TC 512 thermal cycler (Barloworld Scientific). Sequencing was performed both in-house (ABI 3730 Sequencer) and at an external facility (Microsynth, Switzerland). The sequences were assembled and edited manually using Geneious Pro 3.6.2. software. Phylogenetic analysis was performed with the software package MEGA version 4.1 (Kumar et al., 2001) following multiple alignment of data by CLUSTAL_X2 (Thompson et al., 1997). Phylogenetic trees were reconstructed by using the neighbour-joining, minimal evolution, maximum-parsimony and maximum-likelihood algorithms. Evolutionary distances were computed using the Kimura-2 model and the maximum composite likelihood method. Maximum-likelihood analysis was performed using Garli (Zwickl, 2006). These analyses were performed using 1000 bootstrap resamplings.

Comparison of a $1430 \mathrm{bp}$ fragment of the 16S rRNA gene with sequences deposited in GenBank indicated that the strains belong to the family Cytophagaceae, showing the highest level of sequence similarity to $S$. panaciterrae Gsoil $1519^{\mathrm{T}}(89.5 \%)$, Spirosoma rigui $\mathrm{WPCB}^{\mathrm{T}} 18^{\mathrm{T}}(89.4 \%)$, S. linguale $\mathrm{LMG} 10896^{\mathrm{T}}(88.1 \%)$, Rudanella lutea $5715 \mathrm{~S}-11^{\mathrm{T}}(86.7 \%)$ and Fibrella aestuarina BUZ $2^{\mathrm{T}}$ $(86.0 \%)$. These values are lower than the threshold level of $95 \%$ that is generally used to delineate a new genus (Ludwig et al., 1998). Fig. 1 shows that strain BUZ $3^{\mathrm{T}}$ forms a distinct clade in the neighbour-joining phylogenetic tree supported by a high bootstrap value, in line with the other 


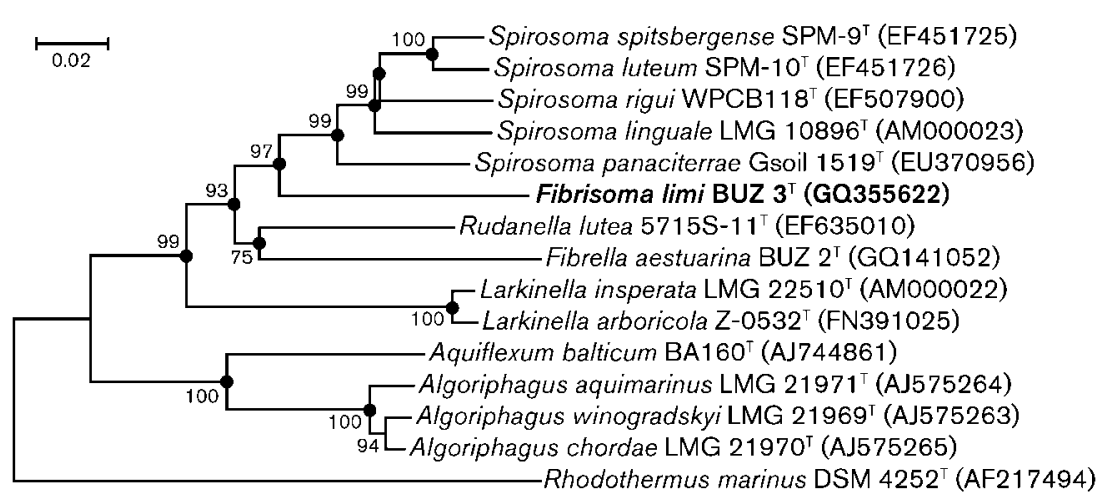

Fig. 1. Neighbour-joining phylogenetic tree based on 16S rRNA gene sequences showing the relationship of strain BUZ $3^{\top}$ with representative members of the family Cytophagaceae. Bootstrap values (expressed as percentages of 1000 replications) greater than $70 \%$ are shown at branch nodes. Accession numbers are given in parentheses. The tree was rooted using Rhodothermus marinus DSM $4252^{\top}$ as the outgroup. Filled circles indicate that the corresponding branches were also recovered in the maximum-likelihood tree. Bar, 0.02 substitutions per nucleotide position. phylogenetic inference methods employed (data not shown). The type strains of the type species of the genera Spirosoma, Rudanella and Fibrella were selected as reference strains and studied in parallel to the novel isolate in all phenotypic tests.

Comparison of strains BUZ $3^{\mathrm{T}}$ and BUZ 4 based on DNADNA hybridization analysis (99.7\% reassociation value), $16 \mathrm{~S}$ rRNA gene sequences ( $99.6 \%$ similarity) and phenotypic profile (carbon utilization, growth conditions and enzyme production) indicated that they belong to the same species. The only difference detected between strain BUZ $3^{\mathrm{T}}$ and strain BUZ 4 was the intensity of colony colour on R2A. Strain BUZ $3^{\mathrm{T}}$ was taken as type strain and characterized with a polyphasic approach.

The Gram reaction was determined using the $\mathrm{KOH}$ test as described by Tindall et al. (2007). Bacterial cell morphology and gliding motility (Bernardet et al., 2002) were observed under a light microscope (BX-51; Olympus) from liquid cultures grown in Spirosoma medium (SM; DSMZ Medium 7) for 1 day. For transmission (CM100; Philips) and scanning (Gemini; Zeiss) electron microscopy, cells were grown for 3 days in R2A broth at $30{ }^{\circ} \mathrm{C}$. Cells for transmission electron microscopy were high-pressure frozen (EMPact2; Leica Microsystems) and freeze-substituted with anhydrous acetone with $2 \% \mathrm{OsO}_{4}$ (EMAFS2; Leica) before embedding in Epon (Sigma). For scanning electron microscopy, cells were chemically fixed with $2.5 \%$ glutaraldehyde in PBS, dehydrated with a graded ethanol series, critical point dried and coated with $5 \mathrm{~nm}$ platinum. The presence of flagella was assessed by transmission electron microscopy after negative staining with $2 \%$ aqueous phosphotungstic acid.

Physiological and biochemical tests were performed at $30{ }^{\circ} \mathrm{C}$ unless otherwise indicated. Catalase activity was determined by adding a drop of $3 \% \mathrm{H}_{2} \mathrm{O}_{2}$ to colonies. Oxidase activity was assessed by using the bioMérieux kit according to the manufacturer's protocol. Flexirubin-type pigments were detected based on a colour shift after exposure to $20 \%(\mathrm{w} / \mathrm{v})$ $\mathrm{KOH}$ solution (Reichenbach, 1992).

Pigments were extracted as described by Gosink et al. (1998) using 99\% ethanol. The absorption spectrum between 350 and $800 \mathrm{~nm}$ was measured with a spectrophotometer (SpectraMax 384 Plus; Molecular Devices) after incubation for $20 \mathrm{~min}$ in the dark.

Growth was tested in R2A, SM, nutrient broth (NB; Becton Dickinson), $0.2 \%$ peptone water and $0.5 \%$ yeast water and on trypticase soy agar (TS; Becton Dickinson), yeast extract tryptone agar (YT; Becton Dickinson), blood agar (Merck) and MacConkey agar (Merck). Since strain BUZ $3^{\mathrm{T}}$ grew well in R2A and SM broths, these two media were used for further analysis. Physiological and biochemical properties of strain BUZ $3^{\mathrm{T}}$ were determined using API 20NE, API 20E, API 50CH and API ZYM strips (bioMérieux) following the manufacturer's instructions. API $50 \mathrm{CH}$ strips were inoculated with cells suspended in AUX medium (bioMérieux). API 20NE, API 20E and API 50CH strips were inspected after 3 and 7 days at $30{ }^{\circ} \mathrm{C}$, whereas API ZYM strips were read after $5 \mathrm{~h}$ at $37^{\circ} \mathrm{C}$. Some of the substrates included in the API 50CH strip, namely glucose, arabinose, lactose and maltose, were also tested by the conventional method using blue green algae medium (BG 11; Rippka et al., 1979) as minimal medium with $0.2 \%$ $(\mathrm{w} / \mathrm{v})$ substrate. The temperature range for growth was determined in R2A broth by growing cultures at 4, 10, 15, 20, 30, 37 and $40{ }^{\circ} \mathrm{C}$. The $\mathrm{pH}$ range for growth was examined in SM broth adjusted to $\mathrm{pH} 5.0-11.0$ (at $1 \mathrm{pH}$ unit intervals) using $\mathrm{KHPO}_{4}$ and $\mathrm{K}_{2} \mathrm{HPO}_{4}$ prior to autoclaving. Higher $\mathrm{pH}$ was reached with additional $\mathrm{NaOH}$. The $\mathrm{pH}$ was verified after autoclaving with $\mathrm{pH}$ strips. Growth at different temperatures and $\mathrm{pH}$ was observed for up to one week. Additionally, tolerance of sodium chloride was tested on R2A plates adjusted to $0-10 \% \mathrm{NaCl}$ (at $0.5 \%$ intervals). Anaerocult C (Merck) was used for generating an oxygen depleted $\left(5-7 \% \mathrm{O}_{2}\right)$ and carbon dioxide enriched $\left(8-10 \% \mathrm{CO}_{2}\right)$ atmosphere in anaerobe jars. Growth was monitored for up to one week. Hydrolysis of starch, xylan, CM-cellulose, pectin, amylopectin, agar and agarose was tested by adding $0.5 \%$ of the respective polysaccharide to nutrient agar solidified with gellan gum. After 3 to 5 days of incubation, the plates were flooded with iodine solution. A positive test was indicated by a colourless area around cell growth. Hydrolysis of casein was tested on milk agar prepared according to the 
Table 1. Phenotypic properties of strain BUZ $3^{\top}$ and the type strains of its closest neighbours

All data are from this study except for the DNA G + C contents of Rudanella lutea DSM $1938^{\mathrm{T}}$ and S. linguale DSM $74^{\mathrm{T}}$, which are taken from Weon et al. (2008), and of Fibrella aestuarina BUZ $2^{\mathrm{T}}$, taken from Filippini et al. (2011). In the API ZYM strip, all strains are positive for alkaline phosphatase, esterase (C4), esterase lipase (C8), leucine arylamidase, valine arylamidase, cystine arylamidase, trypsin, $\alpha$-chymotrypsin, acid phosphatase, naphthol-AS-BI-phosphohydrolase, $\beta$-glucosidase and $N$-acetyl- $\beta$-glucosaminidase activities. All strains are negative for lipase (C14) and $\beta$-glucuronidase activities. All strains are catalase positive. In API $20 \mathrm{NE}$ and API $20 \mathrm{E}$ strips, all strains are negative for indole and $\mathrm{H}_{2} \mathrm{~S}$ production, glucose fermentation, arginine dihydrolase, urease, lysine decarboxylase and ornithine decarboxylase activities, nitrate reduction, citrate utilization, oxidation of D-glucose, D-mannitol, inositol, D-sorbitol, L-rhamnose, sucrose, melibiose, amygdalin and L-arabinose, and assimilation of D-mannitol, capric acid, adipic acid, malic acid, trisodium citrate and phenylacetic acid. All strains are positive for aesculin hydrolysis and $\beta$-galactosidase activity. In API $50 \mathrm{CH}$ strips, all strains are positive for aesculin assimilation and negative for glycerol, erythritol, D-arabinose, L-xylose, D-adonitol, L-sorbose, L-rhamnose, dulcitol, inositol, D-mannitol, D-sorbitol, xylitol, D-tagatose, D- and L-fucose, D- and L-arabitol and potassium 5-ketogluconate assimilation. All strains are positive for amylopectin hydrolysis. All strains are resistant to amikacin, colistin, gentamicin, kanamycin and polymyxin B. All strains are sensitive to amoxicillin, amoxicillin/clavulanic acid, chloramphenicol, ciprofloxacin, penicillin G, rifampicin, streptomycin and tetracycline. +, Positive; w, weakly positive; -, negative.

\begin{tabular}{|c|c|c|c|c|}
\hline Characteristic & BUZ $3^{T}$ & $\begin{array}{c}\text { Spirosoma linguale } \\
\text { DSM } 74^{\mathrm{T}}\end{array}$ & $\begin{array}{l}\text { Rudanella lutea } \\
\text { DSM } 19387^{\mathrm{T}}\end{array}$ & $\begin{array}{l}\text { Fibrella aestuarina } \\
\qquad \mathrm{BUZ} 2^{\mathrm{T}}\end{array}$ \\
\hline Cell morphology & Rods and filaments & $\begin{array}{c}\text { Ring-like and } \\
\text { horseshoe-shaped }\end{array}$ & Rods and filaments & Rods and filaments \\
\hline Colony colour & Orange & Yellow & Orange & Pink \\
\hline Carotenoid pigment peaks (max. in bold) & $450,476 \mathrm{~nm}$ & $450,476 \mathrm{~nm}$ & $450,476,506 \mathrm{~nm}$ & $482,506 \mathrm{~nm}$ \\
\hline Temperature range $\left({ }^{\circ} \mathrm{C}\right)$ & $10-40$ & $4-37$ & $10-40$ & $10-40$ \\
\hline pH range (optimum) & $6-7$ & $6-8(8)$ & $6.0-11.0(7)$ & $6-8(7)$ \\
\hline Tolerance to $\mathrm{NaCl}(\%)$ & $0-2$ & $0-1.25$ & $0-2$ & $0-0.5$ \\
\hline Growth on peptone & - & - & $\mathrm{w}$ & - \\
\hline Oxidase activity & - & + & - & - \\
\hline \multicolumn{5}{|l|}{ Hydrolysis of: } \\
\hline Gelatin & + & - & - & + \\
\hline Starch & $\mathrm{w}$ & $\mathrm{w}$ & $\mathrm{w}$ & + \\
\hline CM-cellulose & - & - & - & + \\
\hline Agar & + & - & - & + \\
\hline Xylan & $\mathrm{w}$ & - & + & + \\
\hline Casein & $\mathrm{W}$ & - & + & + \\
\hline Agarose & + & - & - & + \\
\hline \multicolumn{5}{|l|}{ Assimilation of (API20NE and $50 \mathrm{CH})$ : } \\
\hline D-Glucose & - & + & - & + \\
\hline L-Arabinose & - & $\mathrm{W}$ & - & + \\
\hline D-Mannose & - & + & - & + \\
\hline $\mathrm{N}$-Acetylglucosamine & - & + & - & + \\
\hline Maltose & - & + & - & + \\
\hline D-Fructose & - & + & - & + \\
\hline Raffinose & - & + & - & + \\
\hline Potassium gluconate & - & - & - & $\mathrm{w}$ \\
\hline Methyl $\beta$-D-xylopyranoside & - & - & - & + \\
\hline D-Lyxose & - & + & - & - \\
\hline Glycogen & - & - & - & + \\
\hline Arbutin & - & - & - & + \\
\hline D-Ribose & - & - & - & + \\
\hline D-Xylose & - & + & - & + \\
\hline D-Galactose & - & + & - & + \\
\hline Methyl $\alpha$-D-mannopyranoside & - & + & - & + \\
\hline Methyl $\alpha$-D-glucopyranoside & - & + & - & + \\
\hline Amygdalin & - & + & - & $\mathrm{w}$ \\
\hline Salicin & - & + & - & + \\
\hline Cellobiose & - & + & - & + \\
\hline Lactose & - & + & - & + \\
\hline Melibiose & - & + & - & + \\
\hline Sucrose & - & + & - & + \\
\hline
\end{tabular}


Table 1. cont.

\begin{tabular}{|c|c|c|c|c|}
\hline Characteristic & BUZ $3^{T}$ & $\begin{array}{c}\text { Spirosoma linguale } \\
\text { DSM } 74^{\mathrm{T}}\end{array}$ & $\begin{array}{c}\text { Rudanella lutea } \\
\text { DSM } 19387^{T}\end{array}$ & $\begin{array}{l}\text { Fibrella aestuarina } \\
\qquad \mathrm{BUZ} 2^{\mathrm{T}}\end{array}$ \\
\hline Trehalose & - & + & - & + \\
\hline Melezitose & - & + & - & + \\
\hline Starch & - & + & - & + \\
\hline Gentiobiose & - & $\mathrm{w}$ & - & + \\
\hline Potassium 2-ketogluconate & - & - & - & w \\
\hline \multicolumn{5}{|l|}{ Enzymic activity (API ZYM) } \\
\hline$\alpha$-Fucosidase & - & - & - & + \\
\hline$\alpha$-Mannosidase & + & + & - & + \\
\hline$\alpha$-Glucosidase & + & + & - & + \\
\hline$\alpha$-Galactosidase & + & + & - & + \\
\hline
\end{tabular}

Sigma recipe (15 g agar, $10 \mathrm{ml}$ fresh milk, $5 \mathrm{~g}$ peptone and 1 g yeast extract $1^{-1}$ ) as described elsewhere (Filippini et al., 2011).

Susceptibility to antibiotics was determined by using the disc-diffusion method on R2A plates. The following antibiotics (bioMérieux) were tested ( $\mu \mathrm{g}$ per disc, unless indicated): amikacin (30), amoxicillin (10), amoxicillin/ clavulanic acid (20/10), chloramphenicol (30), ciprofloxacin (5), colistin (30 U), gentamicin sulfate (10), kanamycin (30), penicillin G (10 U), polymyxin B (300 U), rifampicin (30), streptomycin (10), tetracycline (30) and vancomycin (30). Results were interpreted according to the guidelines set forth by the Clinical and Laboratory Standards Institute (CLSI, 2008).

Strain BUZ $3^{\mathrm{T}}$ produced an orange pigment with wavelength absorbance spectral peaks at 450 and $476 \mathrm{~nm}$, a spectrum similar to that of $S$. linguale DSM $74^{\mathrm{T}}$ but with the major peak at $476 \mathrm{~nm}$ (see Supplementary Figure S1 available in IJSEM Online). Rudanella lutea DSM $19387^{\mathrm{T}}$ produced a third peak at $506 \mathrm{~nm}$ in addition to the two peaks mentioned above. The pink-coloured Fibrella aestuarina BUZ $2^{\mathrm{T}}$ had two peaks at 482 and $506 \mathrm{~nm}$, with a major peak at $482 \mathrm{~nm}$. All of these peaks are in the range reported for carotenoid pigments (Asker et al., 2007).

Phenotypic characteristics of strain BUZ $3^{\mathrm{T}}$ are given in Table 1 and in the genus and species descriptions.

For fatty acid analysis, strains BUZ $3^{\mathrm{T}}$, R. lutea DSM $19387^{\mathrm{T}}$, S. linguale DSM $74^{\mathrm{T}}$ and Fibrella aestuarina BUZ $2^{\mathrm{T}}$ were grown in SM broth for three days at room temperature. Fatty acids were analysed by the Identification Service of the Deutsche Sammlung von Mikroorganismen und Zellkulturen (DSMZ, Braunschweig, Germany) according to the standard protocol of the MIDI/Hewlett Packard Microbial Identification System (Sasser, 1990). Respiratory quinone and polar lipid analyses, determination of the DNA
$\mathrm{G}+\mathrm{C}$ content of strain BUZ $3^{\mathrm{T}}$ and DNA-DNA hybridization between strains BUZ $3^{\mathrm{T}}$ and BUZ 4 were also carried out by the DSMZ and Dr B. J. Tindall.

Cellular fatty acid profiles of strain BUZ $3^{\mathrm{T}}$ and its closest relatives are shown in Table 2 . The dominant fatty acids of strain BUZ $3^{\mathrm{T}}$ were summed feature 3 (comprising $\mathrm{C}_{16: 1} \omega 7 c$ and/or iso- $\left.\mathrm{C}_{15: 0} \quad 2-\mathrm{OH} ; 29.3 \%\right), \mathrm{C}_{16: 1} \omega 5 c$ $(23.2 \%)$ and iso- $\mathrm{C}_{17: 0} 3-\mathrm{OH}(13.7 \%)$. Although the overall fatty acid compositions of the four strains were rather similar, strain BUZ $3^{\mathrm{T}}$ could be distinguished from its closest phylogenetic neighbours by smaller proportions of summed feature 3 and $\mathrm{C}_{16: 0} \quad 3-\mathrm{OH}$, and larger proportions of $\mathrm{C}_{16: 1} \omega 5 c$, iso- $\mathrm{C}_{17: 0} 3-\mathrm{OH}, \mathrm{C}_{17: 0} 2-\mathrm{OH}$, $\mathrm{C}_{16: 0} 2-\mathrm{OH}$ and anteiso- $\mathrm{C}_{15: 0}$.

Menaquinone 7 (MK-7) was the only respiratory quinone found in strain BUZ $3^{\mathrm{T}}$, similar to members of the genera Spirosoma and Fibrella. MK-7 was also the major respiratory quinone in $R$. lutea DSM $19387^{\mathrm{T}}$, but a small amount of MK-6 was also found.

The major polar lipid of strain BUZ $3^{\mathrm{T}}$ was phosphatidylethanolamine, but several unidentified aminolipids and aminophospholipids were also detected (Supplementary Fig. S2). The polar lipid profile of strain BUZ $3^{\mathrm{T}}$ shared several similarities with that of Fibrella aestuarina BUZ $2^{\mathrm{T}}$ (Filippini et al., 2011), which was isolated from the same location, whereas the profile of strain BUZ $3^{\mathrm{T}}$ exhibited more differences from the profiles of $S$. linguale DSM $74^{\mathrm{T}}$ and $R$. lutea DSM $19387^{\mathrm{T}}$, published by Weon et al. (2008). Strain BUZ $3^{\mathrm{T}}$ possessed an aminolipid (AL3) that was absent in Fibrella aestuarina, while lacking a phospholipid (PL2) that was present in Fibrella aestuarina. Besides these two differences, the profiles of strain BUZ $3^{\mathrm{T}}$ and Fibrella aestuarina were similar. In comparison to $S$. linguale, strain BUZ $3^{\mathrm{T}}$ contained three aminophospholipids instead of one and three aminolipids (AL) instead of two. In particular, AL3 was not present in S. linguale. Moreover, strain BUZ $3^{\mathrm{T}}$ 
Table 2. Fatty acid content (\%) of strain BUZ $3^{\top}$ and its closest neighbours

Strains: 1 , BUZ $3^{\mathrm{T}} ; 2$, Spirosoma linguale DSM $74^{\mathrm{T}} ; 3$, Rudanella lutea DSM $19387^{\mathrm{T}}$; 4, Fibrella aestuarina BUZ $2^{\mathrm{T}}$. Values for fatty acids amounting to $<1 \%$ of the total fatty acids in all strains are not shown. tr, Trace amounts $(<1 \%)$; ND, not detected. All data are from this study; bacteria were grown in SM broth at room temperature for 3 days.

\begin{tabular}{|c|c|c|c|c|}
\hline Fatty acid & 1 & 2 & 3 & 4 \\
\hline \multicolumn{5}{|l|}{ Straight-chain } \\
\hline $\mathrm{C}_{15: 0}$ & $\operatorname{tr}$ & $\operatorname{tr}$ & 1.1 & 1.0 \\
\hline $\mathrm{C}_{16: 0}$ & 3.8 & 3.7 & 4.3 & 9.8 \\
\hline \multicolumn{5}{|l|}{ Branched saturated } \\
\hline iso- $\mathrm{C}_{13: 0}$ & $\mathrm{ND}$ & 2.0 & $\mathrm{ND}$ & ND \\
\hline iso- $\mathrm{C}_{15: 0}$ & 8.9 & 7.9 & 8.3 & 11.9 \\
\hline iso- $\mathrm{C}_{16: 0}$ & $\operatorname{tr}$ & $\operatorname{tr}$ & 1.3 & 1.3 \\
\hline iso- $\mathrm{C}_{17: 0}$ & $\operatorname{tr}$ & $\operatorname{tr}$ & $\operatorname{tr}$ & 3.4 \\
\hline anteiso- $\mathrm{C}_{15: 0}$ & 4.9 & 2.0 & 1.8 & 2.1 \\
\hline anteiso- $\mathrm{C}_{17: 0}$ & $\operatorname{tr}$ & $\operatorname{tr}$ & $\operatorname{tr}$ & 1.7 \\
\hline \multicolumn{5}{|l|}{ Hydroxy } \\
\hline iso- $\mathrm{C}_{15: 0} 3-\mathrm{OH}$ & 2.7 & 2.6 & 2.3 & 1.3 \\
\hline $\mathrm{C}_{16: 0} 2-\mathrm{OH}$ & 2.5 & ND & $\operatorname{tr}$ & ND \\
\hline $\mathrm{C}_{16: 0} 3-\mathrm{OH}$ & $\operatorname{tr}$ & 2.2 & 3.6 & 1.6 \\
\hline $\mathrm{C}_{17: 0} 2-\mathrm{OH}$ & 1.7 & $\operatorname{tr}$ & $\operatorname{tr}$ & $\operatorname{tr}$ \\
\hline iso- $\mathrm{C}_{17: 0} 3-\mathrm{OH}$ & 13.7 & 7.5 & 6.8 & 9.3 \\
\hline \multicolumn{5}{|l|}{ Mono-unsaturated } \\
\hline $\mathrm{C}_{16: 1} \omega 5 c$ & 23.2 & 18.1 & 21.2 & 17.5 \\
\hline iso- $\mathrm{C}_{17: 1} \omega 9 c$ & 1.5 & $\operatorname{tr}$ & $\operatorname{tr}$ & 1.2 \\
\hline Summed feature $3^{\star}$ & 29.3 & 46.1 & 42 & 33.1 \\
\hline Summed feature 4 & 1.3 & $\operatorname{tr}$ & $\operatorname{tr}$ & $\operatorname{tr}$ \\
\hline Unknown 16.582 & 1.2 & $\operatorname{tr}$ & $\operatorname{tr}$ & $\operatorname{tr}$ \\
\hline
\end{tabular}

* Summed features are groups of two or three fatty acids that could not be separated by GLC using the MIDI system. Summed feature 3 comprised $\mathrm{C}_{16: 1} \omega 7 c$ and/or iso- $\mathrm{C}_{15: 0}$ 2-OH. Summed feature 4 comprised iso- $\mathrm{C}_{17: 1} \mathrm{I}$ and/or anteiso- $\mathrm{C}_{17: 1} \mathrm{~B}$.

showed a reduced number of unspecified lipids (L): only two were detected in comparison to the seven observed in $S$. linguale. The number of unspecified lipids also distinguished strain BUZ $3^{\mathrm{T}}$ from R. lutea. The latter presented five such lipids in its profile. Both $S$. linguale and $R$. lutea had the lipids labelled as L3, L7 and L9 (Weon et al., 2008) as dominant lipids in their profiles. These were missing in the profile of strain BUZ $3^{\mathrm{T}}$. Additionally, strain BUZ $3^{\mathrm{T}}$ differed from $R$. lutea by the presence of aminophospholipids and AL3, both absent in R. lutea.

The DNA G + C content of strain BUZ $3^{\mathrm{T}}$ was $52.0 \mathrm{~mol} \%$, which is in the range reported for members of the genus Spirosoma (Larkin \& Borrall, 1984). This value is slightly lower than those determined for members of the genera Fibrella (Filippini et al., 2011) and Rudanella (Weon et al., 2008).

Based on this polyphasic analysis, we propose that strain BUZ $3^{T}$ represents a novel genus and species in the family
Cytophagaceae, for which the name Fibrisoma limi gen. nov., sp. nov. is proposed.

\section{Description of Fibrisoma gen. nov.}

Fibrisoma [Fi.bri.so'ma. L. n. fibra a fibre, filament; $-i-$ connecting vowel; Gr. neut. n. soma body; N.L. neut. n. Fibrisoma filamentous body (bacterium)].

Gram-staining-negative and non-motile rods able to form filaments. Cells are facultatively anaerobic. Catalasepositive and oxidase-negative. Nitrate is not reduced. Carotenoid-type pigments are produced but flexirubintype pigments are not produced. The predominant cellular fatty acids are summed feature $3\left(\mathrm{C}_{16: 1} \omega 7 c\right.$ and/or iso$\left.\mathrm{C}_{15: 0} 2-\mathrm{OH}\right), \mathrm{C}_{16: 1} \omega 5 c$ and iso- $\mathrm{C}_{17: 0} 3-\mathrm{OH}$. The major polar lipid is phosphatidylethanolamine, but three unidentified aminophospholipids and three aminolipids also occur. The only respiratory quinone is MK-7. The DNA $\mathrm{G}+\mathrm{C}$ content of the type strain of the type species is $52.0 \mathrm{~mol} \%$. Phylogenetically, the genus belongs to the family Cytophagaceae within the phylum Bacteroidetes. The type species is Fibrisoma limi.

\section{Description of Fibrisoma limi sp. nov.}

Fibrisoma limi (li'mi. L. gen. n. limi of/from mud).

Displays the following properties in addition to those given in the genus description. After 1 day of growth in SM, filaments are $1.1 \mu \mathrm{m}$ in diameter and $6.9-86.2 \mu \mathrm{m}$ in length (Fig. 2). In the earlier exponential growth phase, lengths of up to $366 \mu \mathrm{m}$ can be reached. Colonies on R2A are orange, convex and circular with regular edges. Flagellar and gliding motility are absent. Growth occurs in R2A, SM, NB, $0.5 \%$ yeast water and on YT but not on blood, MacConkey and TS agars or in peptone water. The $\mathrm{pH}$ range for growth is 6.0-7.0. The temperature range for growth within 1 week is $10-40{ }^{\circ} \mathrm{C}$ (optimum $20-30{ }^{\circ} \mathrm{C}$ ). Does not require $\mathrm{NaCl}$ for growth but tolerates up to $2 \%$ (w/v) NaCl. Agar, agarose and amylopectin are hydrolysed and starch, casein and xylan are weakly hydrolysed (as shown by haloes around the colonies). Pectin and CMcellulose are not hydrolysed. In the API ZYM strip, trypsin, $\alpha$-chymotrypsin, $\alpha$-galactosidase, $\beta$-galactosidase, $\alpha$-glucosidase, alkaline phosphatase, esterase (C4), esterase lipase (C8), leucine arylamidase, valine arylamidase, cystine arylamidase, acid phosphatase, naphthol-AS-BI-phosphohydrolase, $\beta$-glucosidase, $N$-acetyl- $\beta$-glucosaminidase and $\alpha$-mannosidase activities are present; lipase (C14), $\beta$ glucuronidase and $\alpha$-fucosidase activities are absent. In the API 20NE strip, positive reactions are observed for $\beta$ galactosidase, aesculin assimilation and gelatin hydrolysis; negative reactions for nitrate reduction, indole production, glucose fermentation, arginine dihydrolase and urease activities, and assimilation of glucose, arabinose, mannose, mannitol, $\mathrm{N}$-acetylglucosamine, maltose, potassium gluconate, capric acid, adipic acid, malate, trisodium citrate and phenylacetic acid. In the API 20E strip, negative results are 

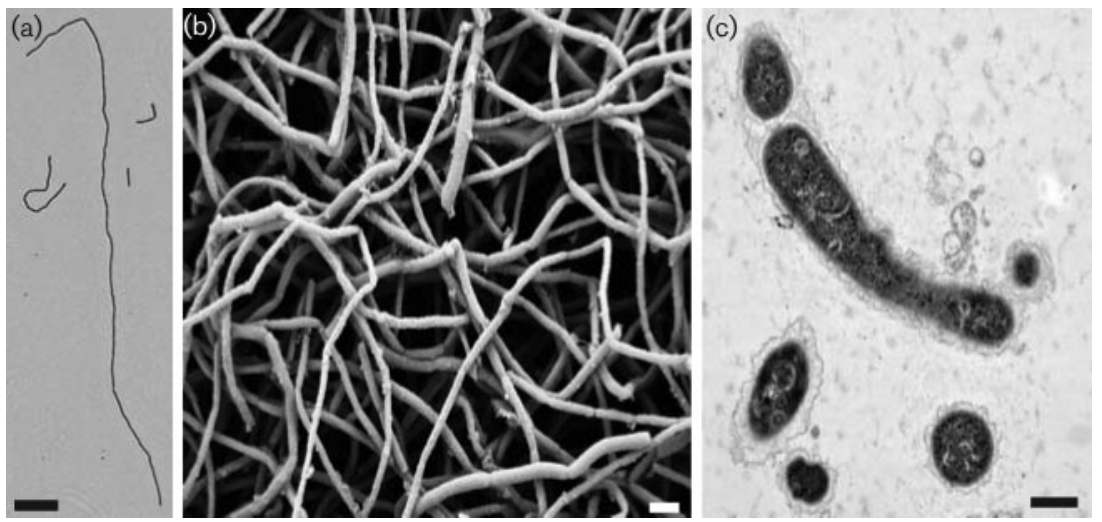

Fig. 2. Cellular morphology of strain BUZ $3^{\top}$. Cells are rod-shaped and form filaments; light micrograph (a), scanning electron micrograph (b) and transmission electron micrograph (c). Bars, $20 \mu \mathrm{m}$ (a), $2 \mu \mathrm{m}$ (b) and $0.5 \mu \mathrm{m}$ (c).

observed for arginine dihydrolase, lysine decarboxylase, ornithine decarboxylase and urease activities, citrate utilization, and $\mathrm{H}_{2} \mathrm{~S}$ and indole production. In the API $50 \mathrm{CH}$ strip after 7 days of incubation, aesculin is the only substrate assimilated; all other substrates are not assimilated. No growth on glucose, arabinose, lactose or maltose in BG 11 medium. Resistant to amikacin $(30 \mu \mathrm{g})$, colistin (30 U), gentamicin $(10 \mu \mathrm{g})$, kanamycin $(30 \mu \mathrm{g})$ and polymyxin B (300 U). Sensitive to amoxicillin $(10 \mu \mathrm{g})$, amoxicillin/clavulanic acid $(20 / 10 \mu \mathrm{g})$, chloramphenicol $(30 \mu \mathrm{g})$, ciprofloxacin $(5 \mu \mathrm{g})$, penicillin $\mathrm{G}(10 \mathrm{U})$, rifampicin $(30 \mu \mathrm{g})$, streptomycin $(30 \mu \mathrm{g})$ and tetracycline $(30 \mu \mathrm{g})$. Intermediate sensitivity to vancomycin $(10 \mu \mathrm{g})$.

The type strain, BUZ $3^{\mathrm{T}}\left(=\mathrm{DSM} 22564^{\mathrm{T}}=\mathrm{CCUG} 58137^{\mathrm{T}}\right.$ ), was isolated from mud in a tidal flat on the North Sea Coast of Germany.

\section{Acknowledgements}

This work was supported by the Faculty of Science of the University of Zurich. We thank W.-T. Im and C. N. Seong for kindly providing the submitted papers on the characterization of Spirosoma panaciterrae and Spirosoma rigui. We would like to thank M. Laturnus for help during environmental sampling, G. Barmettler and K. Marquardt for performing electron microscopy and M. Eisenring for help during phenotypic tests. We thank the editor, J.-F. Bernardet, and the anonymous reviewers for their help in improving this article.

\section{References}

Asker, D., Beppu, T. \& Ueda, K. (2007). Unique diversity of carotenoid-producing bacteria isolated from Misasa, a radioactive site in Japan. Appl Microbiol Biotechnol 77, 383-392.

Baik, K. S., Kim, M. S., Park, S. C., Lee, D. W., Lee, S. D., Ka, J.-O., Choi, S. K. \& Seong, C. N. (2007). Spirosoma rigui sp. nov., isolated from fresh water. Int J Syst Evol Microbiol 57, 2870-2873.

Bernardet, J.-F., Nakagawa, Y. \& Holmes, B. (2002). Proposed minimal standards for describing new taxa of the family Flavobacteriaceae and emended description of the family. Int J Syst Evol Microbiol 52, 1049-1070.

CLSI (2008). Performance standards for antimicrobial susceptibility testing; eighteenth informational supplement. M100-S18. Wayne, PA: Clinical and Laboratory Standards Institute.
Filippini, M., Svercel, M., Laczko, E., Kaech, A., Ziegler, U. \& Bagheri, H. C. (2011). Fibrella aestuarina gen. nov., sp. nov., a filamentous bacterium of the family Cytophagaceae isolated from a tidal flat, and emended description of the genus Rudanella Weon et al., 2008. Int J Syst Evol Microbiol 61, 184-189.

Finster, K. W., Herbert, R. A. \& Lomstein, B. A. (2009). Spirosoma spitsbergense sp. nov. and Spirosoma luteum sp. nov., isolated from a high Arctic permafrost soil, and emended description of the genus Spirosoma. Int J Syst Evol Microbiol 59, 839-844.

Gosink, J. J., Woese, C. R. \& Staley, J. T. (1998). Polaribacter gen. nov., with three new species, $P$. irgensii sp. nov., $P$. franzmannii sp. nov. and $P$. filamentus sp. nov., gas vacuolate polar marine bacteria of the Cytophaga-Flavobacterium-Bacteroides group and reclassification of 'Flectobacillus glomeratus' as Polaribacter glomeratus comb. nov. Int J Syst Bacteriol 48, 223-235.

Kumar, S., Tamura, K., Jakobsen, I. B. \& Nei, M. (2001). MEGA2: molecular evolutionary genetics analysis software. Bioinformatics $\mathbf{1 7}$, 1244-1245.

Larkin, J. M. \& Borrall, R. (1984). Family I. Spirosomaceae Larkin and Borrall 1978, 595 ${ }^{\mathrm{AL}}$. In Bergey's Manual of Systematic Bacteriology, vol. 1, pp. 125-126. Edited by N. R. Krieg \& J. G. Holt. Baltimore: Williams \& Wilkins.

Ludwig, W., Strunk, O., Klugbauer, S., Klugbauer, N., Weizenegger, M., Neumaier, J., Bachleitner, M. \& Schleifer, K. H. (1998). Bacterial phylogeny based on comparative sequence analysis. Electrophoresis 19, 554-568.

Ludwig, W., Euzéby, J. \& Whitman, W. B. (2008). Draft Taxonomic Outline of the Bacteroidetes, Planctomycetes, Chlamydiae, Spirochaetes, Fibrobacteres, Fusobacteria, Acidobacteria, Verrucomicrobia, Dictyoglomi, and Gemmatimonadetes for Volume 4 of the second edition of Bergey's Manual of Systematic Bacteriology (http://www. bergeys.org/outlines.html).

Reasoner, D. J. \& Geldreich, E. E. (1985). A new medium for the enumeration and subculture of bacteria from potable water. Appl Environ Microbiol 49, 1-7.

Reichenbach, H. (1992). The order Cytophagales. In The Prokaryotes. A Handbook of the Biology of Bacteria: Ecophysiology, Isolation, Identification, Applications, 2nd edn, pp. 3631-3675. Edited by A. Balows, H. G. Trüper, M. Dworkin, W. Harder \& K. H. Schleifer. New York: Springer.

Rippka, R., Deruelles, J., Waterbury, J. B., Herdman, M. \& Stanier, R. Y. (1979). Generic assignments, strain histories and properties of pure cultures of cyanobacteria. J Gen Microbiol 111, 1-61.

Sasser, M. (1990). Identification of bacteria by gas chromatography of cellular fatty acids, MIDI Technical Note 101, Newark, DE.

Svercel, M., Christen, D., Moënne-Loccoz, Y., Duffy, B. \& Défago, G. (2009). Effect of long-term vineyard monoculture on rhizosphere 
populations of pseudomonads carrying the antimicrobial biosynthetic genes phlD and/or hcnAB. FEMS Microbiol Ecol 68, 25-36.

Ten, L. N., Xu, J.-L., Jin, F.-X., Im, W.-T., Oh, H.-M. \& Lee, S.-T. (2009). Spirosoma panaciterrae sp. nov., isolated from soil. Int J Syst Evol Microbiol 59, 331-335.

Thompson, J. D., Gibson, T. J., Plewniak, F., Jeanmougin, F. \& Higgins, D. G. (1997). The CLUSTAL_X windows interface: flexible strategies for multiple sequence alignment aided by quality analysis tools. Nucleic Acids Res 25, 4876-4882.

Tindall, B. J., Sikorski, J., Smibert, R. A. \& Krieg, N. R. (2007). Phenotypic characterization and the principles of comparative systematics. In Methods for General and Molecular Microbiology, 3rd edn, pp. 330-393. Edited by T. J. Beveridge, J. A. Breznak, G. A. Marzluf, T. M. Schmidt \& L. R. Snyder. Washington, DC: American Society for Microbiology.

Weon, H.-Y., Noh, H.-J., Son, J.-A., Jang, H. B., Kim, B.-Y., Kwon, S.-W. \& Stackebrandt, E. (2008). Rudanella lutea gen. nov., sp. nov., isolated from an air sample in Korea. Int J Syst Evol Microbiol 58, 474-478.

Zwickl, D. J. (2006). Genetic algorithm approaches for the phylogenetic analysis of large biological sequence datasets under the maximum likelihood criterion. $\mathrm{PhD}$ dissertation, University of Texas at Austin, Austin, TX, USA. 